PREPRINT: Folqué, M., Escrig-OImedo, E., \& Corzo Santamaría, T. (2021). Sustainable development and financial system: Integrating ESG risks through sustainable investment strategies in a climate change context. Sustainable Development. DOI:

https://doi.org/10.1002/sd.2181

\title{
Sustainable Development and Financial System: Integrating ESG risks through sustainable investment strategies in a climate change context
}

\author{
SHORT RUNNING TITLE: Integrating ESG risks through SI strategies
}

\begin{abstract}
Sustainable Investment funds are one of the most appropriate ways for the financial system to contribute to sustainable development. However, the effective contribution of Sustainable Investment funds can vary widely depending on their management strategy. This paper aims to analyze which strategies or combinations of them allow practitioners to better manage ESG risks in ESG portfolios within a complete framework consistent with global challenges that focus on sustainability and carbon risk scores. To analyze the differences between Sustainable Investment strategies, we adopt a parametric ANOVA method. We find that, on average, funds that only apply negative filters achieve worse ESG risk scores and show worse carbon risk. In sum, this study contributes with more in-depth knowledge about the different outcomes in terms of sustainability risks of the different SI strategies.
\end{abstract}

Keywords: Sustainable Development (SD), Sustainable Investment (SI), Sustainable Investment strategies (SI strategies), Environmental, Social and Governance Risks (ESG risks), climate change, Carbon Risk.

\section{María Folqué}

PhD Candidate. Facultad de Económicas y Empresariales. ICADE. Universidad Pontificia de Comillas. Madrid. Spain

\section{Dr. Elena Escrig -Olmedo}

Senior Lecturer. Finance and Accounting Department

Universitat Jaume I. Castellón. Spain

\section{Prof. Dr. Teresa Corzo}

Decana de la Facultad de Económicas y Empresariales. ICADE. Universidad Pontificia de Comillas. Madrid. Spain 
PREPRINT: Folqué, M., Escrig-Olmedo, E., \& Corzo Santamaría, T. (2021). Sustainable development and financial system: Integrating ESG risks through sustainable investment strategies in a climate change context. Sustainable Development. DOI:

https://doi.org/10.1002/sd.2181

\section{Introduction}

The global sustainability agenda, the mitigation of climate change, and the transition towards a low carbon economy have become permanent features for investors. The opportunities and risks of this scenario require the comprehensive measurement of both financial and sustainability risks in investment portfolios. Financial risks are already integrated into investment processes, but effective risk management should also consider environmental, social, and governance (ESG) risks (Ashwin Kumar et al., 2016; Hübel \& Scholz, 2020).

Nowadays, more and more investors rely on ESG rating providers to measure these risks. These third-party data providers assess firms' ESG performance (Berg et al., 2019), offer ESG metrics as a proxy for sustainability performance (Widyawati, 2020), and have become a key reference in financial markets (Escrig-Olmedo et al., 2019). ESG scores' strengths and shortcomings are increasingly becoming the subject of interest for academia and practitioners. While some authors have warned that performance and risk are different constructs (Semenova \& Hassel, 2015) and others, have put in question the rigorousness of ESG rating agencies' evaluation of corporate sustainability risks (Boiral et al., 2020), some ESG rating providers are changing their focus to identify financially material ESG-related risks, in line with the role that sustainable investment (SI) could play in the transition economy.

Among the metrics analyzed, exposure to carbon and climate risks is gaining relevance amidst the climate change transition of the economy (Görgen et al., 2017). The awareness of climate change impact has already led some institutional investors to reconsider holdings with significant ties to fossil fuels or at least to price in the externalities of fossil fuel consumption (Ibikunle \& Steffen, 2017). Some of them have also considered creating and joining in international initiatives such as Climate Action 100, the Carbon Disclosure Project, the Portfolio Decarbonization Project, or the Global Investor Coalition on Climate Change, among others (Krüger et al. 2018). In sum, many more investors are becoming sensitive to how companies in which they invest perform sustainably (Bradford et al. 2017), looking for additional utility by investing in sustainable companies (Hirschberger et al. 2012), following what Bollen (2007) coined as the multi-attribute utility function of socially responsible investors.

Thus, investors' attitudes have changed, and so have the measurement and integration of ESG risks in the investment processes of mutual funds. Diverse approaches deployed in different strategies usually coexist in investment portfolios. Negative and positive filters of specific industries and activities were the starting approach to build sustainable portfolios. They are still applied, but now they coexist with evolved strategies like integration, engagement, and impact investment. The aggregation of different practices is common in the asset management industry.

While academic literature on SI has mainly focused on comparing its financial performance to conventional investments (Capelle-Blancard \& Monjon, 2012; von Wallis \& Klein, 2015), much less attention has been paid to the effects that applying different $\mathrm{SI}$ strategies could have on effectively managing ESG risks. Different practices of SI can achieve different results (Silva \& 
PREPRINT: Folqué, M., Escrig-OImedo, E., \& Corzo Santamaría, T. (2021). Sustainable development and financial system: Integrating ESG risks through sustainable investment strategies in a climate change context. Sustainable Development. DOI:

https://doi.org/10.1002/sd.2181

Cortez, 2016; Nofsinger \& Varma, 2014), and given the urgency of the societal and economic challenges that climate change and the sustainability agenda pose more in-depth research is required. An analysis that goes beyond the financial performance of $\mathrm{SI}$ funds versus their conventional peers, to focus on sustainability and carbon risks. If $\mathrm{SI}$ is an investment approach that has a potentially positive impact on sustainable development through the integration of not only financial concerns but also long-term ESG criteria into investment decisions (EscrigOlmedo et al., 2017), it seems relevant to test its sustainability and environmental contributions. It is also pertinent to analyze which SI strategies or combination of strategies exhibit lower ESG risks.

For this reason, in contrast to previous literature, the objective of this paper is to study which strategies or combination of SI strategies allow practitioners a better management of ESG risks in ESG portfolios within a complete framework consistent with global challenges that consider sustainability and carbon risk scores. Concretely, the current study addresses the following research question: Which SI strategy achieves the lowest impact of ESG risks on their investment, and therefore facilitates the integration of sustainability into the financial market contributing to sustainable development?

To answer this research question, we propose an empirical analysis focused on equity SI mutual funds registered for sale in Europe. Our study is focused in Europe because it is the region in the world with more $\mathrm{SI}$ assets under management and where is finding more support and impulse in the legislative agenda (GSIA 2019; Eurosif 2018). To gather data on SI Funds, we have used Morningstar Direct database based on Sustainalytics' research, leading information providers in the mutual fund industry. Following Berg et al. (2019), we explain the choice of Morningstar data given the change of methodology announced in 2018, when the ESG data provider shifted from measuring ESG performance to measure ESG risks, including carbon risk. Sustainability risks are the subject of our interest and analysis. Furthermore, as Ammann et al. (2019) show, Morningstar is one of the most influential databases in the market regarding sustainability data, given its ability to reach both institutional and retail investors.

Based on our analysis, we find that, on average, funds that only apply negative filters, achieve a worse ESG risk in terms of Historical Sustainability Score and Portfolio Social Score compared to the funds that integrate more advanced SI strategies (ESG integration, screening combination, engagement and impact investment). The funds that only apply negative filters also show worse carbon risk score.

We contribute to the asset management literature by achieving a more profound knowledge about the different outcomes of the different SI strategies, not only attending to financial performance but widening the focus to global sustainability risks and carbon risk score. In the current global context, adequate analysis and measurement of ESG risks by the financial market seem essential to contribute to the Global Sustainability Agenda and mitigate climate change. Portfolio managers should integrate into their analysis these new components of risk, in addition 
PREPRINT: Folqué, M., Escrig-OImedo, E., \& Corzo Santamaría, T. (2021). Sustainable development and financial system: Integrating ESG risks through sustainable investment strategies in a climate change context. Sustainable Development. DOI:

https://doi.org/10.1002/sd.2181

to the traditional financial risks. This paper's results provide managers and selectors the skills necessary to choose the SI funds that best meet ESG and carbon risks.

The remainder of the paper is organized as follows: Section 2 reviews the relevant literature and states the main hypotheses to be tested. Section 3 describes the methodology, including the econometric model, data, and study variables. Section 4 presents the empirical results and discussion. Finally, Section 5 concludes the study.

\section{Theoretical Framework and hypotheses formulation}

\subsection{Sustainability risks and SI funds}

The overall goal of sustainable development is the long-term stability of the society's needs and the environment, and to achieve this, the financial sector should contribute to a greener and more sustainable economic development. Busch et al. (2015) explored the role of financial markets for sustainable development, suggesting that a reorientation toward a long-term paradigm for sustainable investments is essential.

Financial institutions have started to influence sustainable development through their core business with SI products (Weber et al., 2011). Institutional investors -the major players in the world's financial markets (Sandberg, 2011)- have the opportunity to be an integral part of the global sustainability agenda, integrating sustainability risks into the investment decision-making process through SI. A sustainability risk means "an environmental, social or governance event or condition that, if it occurs, could cause a negative material impact on the value of the investment" (EC, 2019). The consideration of sustainability risks associated with social, environmental, and governance issues (also called ESG risks), has increased among investors (Boiral et al., 2020; Henriksson et al., 2019).

In line with this growing interest, more recently, a branch of academic literature has been focusing on the challenges of assessing sustainability risks given their unpredictability, the methodological issues related to their measurement, and the lack of reliable information (Boiral et al., 2020). Since more and more investors rely on ESG ratings from third-party providers, authors have analyzed the lack of homogeneity of their measurements (Saadaoui \& Soobaroyen, 2018), the sources of these disagreements (Berg et al., 2019), the effects of these disagreements on stock returns (Gibson et al., 2020), the differences between measuring performance and risks (Semenova \& Hassel, 2015) and how to overcome the shortcomings of ESG ratings with alternative measurements of exposure (Henriksson et al., 2019; Hübel \& Scholz, 2020). From another perspective, some authors have shown that a portfolio's sustainability quality can be improved using ESG scores without hampering performance or diversification (Alessandrini \& Jondeau, 2020). Others emphasize that the growth of socially responsible investing and ESG would not have been possible without the research now available from Morningstar and other ESG ratings (Townsend, 2020). 
PREPRINT: Folqué, M., Escrig-OImedo, E., \& Corzo Santamaría, T. (2021). Sustainable development and financial system: Integrating ESG risks through sustainable investment strategies in a climate change context. Sustainable Development. DOI:

https://doi.org/10.1002/sd.2181

Academic literature on $\mathrm{SI}$ is broadening the scope of its attention to transcend the exhausted discussion (Juravle \& Lewis, 2008) of the difference of performance between SI and conventional investments, paying more attention to ESG risk considerations and ESG risk metrics (Widyawati, 2020). According to Van Duren et al. (2016), ESG criteria are starting to be used even by conventional investors - mainly for red-flagging and risk managing. In a previous study on the motives to engage in sustainable investment, Jansson \& Biel (2011) found that institutional investors were prompted by an effort to reduce financial risks. This practice underscores the relevance of evaluating sustainability risks and their materiality when building investment portfolios (GIIN, 2018).

Analyzing the effects of integrating ESG considerations/attributes on portfolio risks, a study of the Spanish market, Ortas et al. (2014) find that SI strategies are less risky, in terms of riskadjusted returns, than the conventional investment approach. Moreover, the lower riskiness of the $\mathrm{SI}$ seems more evident during periods of maximum market instability. Analyzing a sample of US domestic equity funds, Nofsinger \& Varma (2014) encounter evidence of outperformance of SI funds compared to conventional peers during periods of market crisis, but this lower downside risk comes at the cost of underperforming in non-crisis periods. They explain this asymmetric return by the very nature of SI and ESG that offers protection against adverse events during both bull and bear markets. Ashwin Kumar et al. (2016) study the correlation between ESG performance, and stock returns volatility to find that integrating ESG factors into the investment decision can bring lower volatility, achieve superior risk-adjusted returns, and more efficiency, measured by higher Sharpe ratios.

However, considering the risk of SI portfolios in terms of volatility and financial ratios is not the same as analyzing the sustainability risks of the SI portfolios, and different approaches to SI portfolio construction can have different impacts on sustainability (Kölbel et al., 2019).

\subsection{Sustainability risks and SI strategies}

SI funds may integrate non-financial considerations into the investment process by applying a set of investment screens designed to select (positive screens) or to exclude (negative screens) assets from their portfolios (Leite \& Cortez, 2014). Negative screening is considered the oldest SI practice (Renneboog et al. 2008; Trinks \& Scholtens, 2017) and excludes companies or sectors according to social, environmental, or ethical considerations. However, the construction of a portfolio in SI funds can also be based on a positive screening approach to select investments that meet specific standards or reflect beneficial initiatives (Gangi \& Varrone, 2018). Positive filters are usually combined with a "best in class" approach, by which companies are scored according to their level of fulfillment of different ESG criteria.

Renneboog et al. (2008) view the negative and positive screening of filtering as the first and second generation of SI funds. The third generation of SI refers to an integrated approach of selecting companies based on the economic, environmental, and social criteria comprised of both negative and positive screens. ESG integration is "the explicit inclusion by asset managers 
PREPRINT: Folqué, M., Escrig-OImedo, E., \& Corzo Santamaría, T. (2021). Sustainable development and financial system: Integrating ESG risks through sustainable investment strategies in a climate change context. Sustainable Development. DOI:

https://doi.org/10.1002/sd.2181

of ESG risks and opportunities into traditional financial analysis and investment decisions based on a systematic process and appropriate research sources" (Eurosif, 2016). The fourth generation of SI funds combines the third generation with shareholder activism. In recent years, particularly with the launch of the SDG's, another sustainable investment practice, impact investing, is gaining ground. The Global Impact Investment Network (GIIN) defines impact investments as investments made with the intention to generate positive, measurable social, and environmental impact alongside a financial return (GIIN, 2018), focusing on issues related to sustainable development (water, fight against climate change, health, education, etc.). The intentionality and the measurability are crucial elements of this practice, and investors can incorporate impact investing across asset classes and with a variety of return expectations. This investment approach's particular characteristics have led many to consider it a crucial practice for many to achieve the SDGs, highlighting its role in closing the SDG funding gap (Carè \& Wendt, 2018).

The Global Sustainable Investment Alliance -GSIA- (2019) and Eurosif (2018) have classified these screenings, and combination of approaches in seven different strategies: (1) Sustainability themed investments, (2) Best-in-class investment selection, (2) Exclusion of holdings from investment universe, (4) Norms-based screening, (5) Integration of ESG factors in financial analysis, (6) Engagement and voting on sustainability matters, and (7) Impact investment. SI Funds can combine any number of these strategies to create an overall strategy.

The literature on SI practices has examined in depth the relation between screens and the financial performance of SI funds. Focusing on how it relates to the intensity and types of screens used, Barnett and Salomon (2006) and Capelle-Blancard \& Monjon (2014) find a curvilinear relationship. Admitting that the use of different screens can lead to different performance patterns and investment styles, Trinks \& Scholtens (2017) find that the use of negative screening is financially suboptimal due to the opportunity costs. Kempf \& Osthoff (2007) show that in a trading strategy, the maximum abnormal returns are reached when investors employ the bestin-class screening approach. Analyzing this approach, Leite \& Cortez (2014) show that best in class may create difficulties in distinguishing SI from non-SI funds. Bauer et al. (2003) had already argued that by using only a best-in-class approach, the fund manager could choose the least controversial company in any sector, allowing investments in leading companies from industries that are often considered undesirable from a socially responsible perspective. Other practices have received critics on their sustainability focus, particularly the ESG integration, considered as a "less restrictive SI" by Revelli (2017).

According to the GSIA (2019), the most common way to participate in sustainable investing (as measured by assets under management allocated to each strategy) is to implement negative screening. However, this approach is closely followed by ESG integration and corporate engagement strategies. Some authors have linked this evolution to the popularization of ESG data and ratings (Drei et al., 2020). ESG data is now more widely available than even five years ago, changing sustainable investment practices. The dynamics of ESG ratings shape the evolution of sustainable investment to the point where simple negative screening is considered 
PREPRINT: Folqué, M., Escrig-OImedo, E., \& Corzo Santamaría, T. (2021). Sustainable development and financial system: Integrating ESG risks through sustainable investment strategies in a climate change context. Sustainable Development. DOI:

https://doi.org/10.1002/sd.2181

an outdated or non-advanced practice (Townsend, 2020) versus forward-looking ESG analysis, which strives to assess the materiality of nontraditional data to determine which companies are best fit to face sustainability risks. Therefore, more advanced SI strategies (for example integration, engagement \& voting, impact investment, among others) are gaining ground (Eurosif, 2018), allowing the creation of asset portfolios advanced in ESG matters. In this line and based on their research, Alessandrini \& Jondeau (2020) suggest that ESG investing is fundamentally different from screening out sin stocks.

Surprisingly, there are very few academic studies that compare the ESG performance of SI funds according to their sustainability characteristics (ESG attributes). Matallín-Sáez et al. (2019) compare the performance of $\mathrm{SI}$ funds to the level of sustainability attributes accomplished in their portfolio. These characteristics refer to ESG scores. According to this study, funds with high ESG scores seem to experience overall worse performances. This evidence is, however, mainly driven by the behavior of the worst-performing funds. In a study on how SI investors can trigger changes in companies' environmental and social impact, Kolbel et al. (2019) concluded that the impact of shareholder engagement is well supported in the literature, while the impact of capital allocation is only partially supported.

The recent creation of the tools to measure companies and issuers' extra-financial data can explain the lack of studies analyzing the relationship between SI strategies and ESG risks in SI funds. Hence, it is vital to implement more in-depth research that considers which SI strategies and ESG risks could be more significant for SI to thrive as an investment practice and make an accountable contribution to sustainability (Eccles, 2015; Eccles \& Serafeim, 2011, 2013).

Accordingly, the analysis of the ESG risks is related to the first hypothesis of our study:

Hypothesis 1. Funds with advanced SI strategies exhibit lower ESG risks.

\subsection{Climate risk and financial sector}

Limiting climate change is a vital challenge for mankind. Financial institutions can encourage companies to speed up the transition to a low carbon economy (Schoenmaker \& Van Tilburg, 2016). The economic costs of the environmental crisis are already significant from a macro and micro perspective, and could increase. The special report of IPCC (2018) on how to hold global warming to $1.5^{\circ} \mathrm{C}$, concludes that global emissions will need to fall by $45 \%$ from 1990 levels by 2030 (Grantham Research Institute on Climate Change, LSE, \& Initiative for Responsible Investment at the Harvard Kennedy School, 2018).

The transition to a low carbon economy entails risks and opportunities for the financial sector and the asset management industry. Therefore, it is urgent to accelerate low-carbon investments. Louche et al. (2019) define low carbon investments as a financial institution and investor practices that support and facilitate the transition from a fossil-fuel-based economy to a low carbon economy through low carbon and renewable technologies as well as energy 
PREPRINT: Folqué, M., Escrig-OImedo, E., \& Corzo Santamaría, T. (2021). Sustainable development and financial system: Integrating ESG risks through sustainable investment strategies in a climate change context. Sustainable Development. DOI:

https://doi.org/10.1002/sd.2181

efficiency measures. This transition includes policy and legal regulations limiting carbon emissions, new technologies, and changing consumer preferences.

On the one hand, there has to be a shift in investment patterns to limit anthropogenic climate change (Harnisch et al. 2014). Companies and investors should consider any possible action to safeguard the living conditions for future generations (Busch \& Friede, 2018). On the other hand, since ecological and social imbalances could affect the economy and the markets in many ways, institutional investors should be ready to manage these risks. According to Krüger et al. (2018), climate risks may negatively affect the value of assets managed by institutional investors. These authors conducted survey among 439 institutional investors and found that the preferred approaches to managing climate risks are the analyses of carbon footprints and stranded asset risks. The least used tool is the divestment on companies in the portfolio.

Analyzing carbon footprints and climate risks in a portfolio can be arduous since the companies' disclosure of exposure is not universally mandatory or standardized. A branch of academic literature is attempting to solve these limitations by proposing diverse methodologies to evaluate carbon risk and carbon footprints. Schoenmaker \& Van Tilburg (2016), have developed a methodology that measures the carbon-related exposures across the value chain, including direct emissions and indirect ones through lending and investment (scope 1 to scope3). Ritchie \& Dowlatabadi (2015) have coined the term carbon shadow that represents the GHG emissions embodied in an investor's portfolio returns. This metric could be used to estimate exposure to climate risks. Funds with large shadows would face a higher probability of financial loss in low emission scenarios. Institutional investors can use the carbon shadow to modify the asset mix in their portfolios. Görgen et al. (2018) have focused on estimating carbon betas for companies and have found that it is possible for investors to reduce carbon risk in their portfolios without hurting performance.

Another way to managing climate risks should consider exposure to the so-called carbon bubble or the overvaluation of fossil fuel reserves, which leads to the problem of stranded assets. Private oils, gas, and coal mining companies are the owners of $25 \%$ of global fossil-fuel reserves (Schoenmaker \& Van Tilburg, 2016), and if they cannot use them, this should have an impact on their valuations and the portfolios invested on them (Weyzig et al. 2014).

There are different SI strategies for aligning a fund with climate-related investment objectives and for introducing carbon risk in the decision making in portfolio selection. Many investors are already reducing exposure to high-carbon assets, excluding companies or sectors. Divestment may be one of the responses of investors, although, for some authors, it may increase transition risks because a sudden divestment-driven influx of large institutional investors into renewable energy companies could result in a 'green' bubble (Ritchie \& Dowlatabadi, 2015). For this reason, many others opt for dialogue with the companies (Dimson et al., 2015), while other authors have shown that divestment does not harm portfolios. Trinks et al. (2018) compared the financial performance of investment portfolios with and without fossil fuel stocks in the US between 1927 and 2016, finding that the fossil fuel divestment does not seem to harm portfolio 
PREPRINT: Folqué, M., Escrig-OImedo, E., \& Corzo Santamaría, T. (2021). Sustainable development and financial system: Integrating ESG risks through sustainable investment strategies in a climate change context. Sustainable Development. DOI:

https://doi.org/10.1002/sd.2181

performance. In their study on institutional investors' approach to managing carbon risk, Bolton \& Kacperczyk (2019) find that a categorical exclusionary screening approach only partially addresses the carbon risk issue, urging investors to include the demand side of the problem into the analysis.

Considering the diversity of approaches around carbon risk management, we ask ourselves which strategy or combination of strategies of SI results in the portfolios with the lowest carbon risk.

Given the complexity of carbon risk analysis, we hypothesize that investment strategies that do not rely solely on positive or negative filters can generate portfolios with lower carbon risk.

We thus hypothesize:

Hypothesis 2. Funds with advanced SI strategies exhibit lower carbon risk.

To the best of our knowledge, we have not found any study that evaluates the results of SI funds according to their strategy, ESG risk scores, and carbon intensity, i.e., considering all their possible utilities. In this context, we aim to identify which category of SI funds exhibit lower ESG and carbon risk.

\section{Methodology}

\subsection{Data Description}

To test the hypotheses proposed, this study analyzes equity funds registered for sale in Europe labeled by the Morningstar database as "socially conscious." According to Morningstar's definition, "socially conscious" indicates that the fund selectively invests based on certain noneconomic principles (environmental responsibility, human rights, or religious views) and may take a pro-active stance by selectively investing in. This group also includes funds that avoid investing in companies involved in promoting alcohol, tobacco, or gambling, or the defense industry.

The analysis focuses on four main equity categories: Europe Large Cap Equity, Global Large Cap Equity, US Large Mid Cap Equity, and Global Emerging Markets Equity. According to Morningstar Direct data, these categories represent the areas of equity investment with more funds registered for sale in Europe. Since these funds invest in large-cap companies, more information is available to design sustainable portfolios properly. Smaller-sized companies tend to disclose a relatively lower volume of sustainability-related information than large caps (Demerens et al., 2014).

We gather portfolio information about ESG risks from Morningstar Direct. Morningstar uses sustainability data from Sustainalytics, which changed its methodology in 2018 to calculate ESG risks instead of ESG scores. Morningstar did not incorporate the new rating for mutual funds 
PREPRINT: Folqué, M., Escrig-OImedo, E., \& Corzo Santamaría, T. (2021). Sustainable development and financial system: Integrating ESG risks through sustainable investment strategies in a climate change context. Sustainable Development. DOI:

https://doi.org/10.1002/sd.2181

until November 2019, once they had one year of data gathered with the new Sustainalytics' ESG risks methodology. Therefore, all the funds included in our sample have at least one year of data available as of November 31, 2019. Our analysis covers the period November 2018-September 2020.

According to their new methodology, Sustainalytics' ESG Risk Rating approach used by Morningstar "has a clear focus on financial materiality: it measures the degree to which a company's enterprise value is exposed to material ESG issues. Although previous ratings recognized the importance of industry-specific topics, the ESG Risk Rating goes a step further by reflecting the relevance of each ESG issue in each company's unique context within its subindustry. The rating's absolute risk scores allow cross-sectorial ESG risk analysis".

Once the funds were collected, they were classified into five generations, from the most basic to the most advanced SI generation. Based on Renneboog et al. (2008), Eurosif (2018), and GSIA (2019) classifications, and aware of the industry practice of aggregation of strategies, which makes it increasingly challenging to be able to determine individual strategies (Eurosif, 2018), we propose a categorization of SI strategies. To classify the funds in different generations, we use the information provided by Morningstar Direct database in their attributes framework. According to Morningstar, "the attributes framework offers investors a system that classifies the sustainable funds' landscape using funds' own stated objectives."

The funds that only apply negative belong to the first generation. The funds applying negative filters have communicated to Morningstar that overall they employ exclusions. The funds applying positive filters fall under the label ESG incorporation in the database and belong to the second generation. According to Morningstar's definition, these strategies often use positive screens to make their investment choices, tacitly removing companies that do not meet their standards in relevant environmental, social, and/or governance areas. ESG incorporation typically includes best-in-class strategies where managers select investments based on stronger ESG performance relative to peers.

Funds applying both negative and positive filters belong to the third SI generation. If their managers apply either negative or positive filters, or both, and declare to practice engagement, the funds belong to the third generation. In line with the findings of Dimson et al. (2015), we consider that an active ownership policy could result in better management of ESG risks. Hoepner et al. (2017) have found evidence of the effects of engagement with firms in risk reduction. Bertolotti (2020) underscores how the voluntary disclosure of ESG data and the lack of reporting standards make engagement and stewardship more critical.

Finally, the funds classified as impact funds form the fourth generation. These are funds that seek to make a measurable impact in investments on specific issue areas alongside a financial return. Although impact investment was more related to philanthropy and venture capital in its origins(Bugg-Levine \& Emerson, 2011), the launch of SDGs in 2015 has led many listed companies to consider their role in financing these global goals. The so-called SDG investment 
PREPRINT: Folqué, M., Escrig-Olmedo, E., \& Corzo Santamaría, T. (2021). Sustainable development and financial system: Integrating ESG risks through sustainable investment strategies in a climate change context. Sustainable Development. DOI:

https://doi.org/10.1002/sd.2181

case (PWC 2017) has prompted many asset managers to launch impact funds. Usually, impact funds in listed companies align their investments with one or more SDG and establish a set of metrics and key performance indicators (KPIs) to verify their impact. More and more practitioners consider impact investment as the new step in the evolution of SI. In sum, we agree with Bertolotti (2020) when he states that SI, to be effectively sustainable, must have the intention and be relevant in terms of a meaningful impact.

Table 1 shows the SI fund generations according to their underlying strategies.

\{Insert Table 1. Number of funds by category and SI generation Here\}

Table 2 shows the number of all mutual funds in those five categories, according to our classification of generations of SI funds, based on the academic literature and the industry, from non-advanced (first generation) to more advanced (second, third, fourth generations) SI strategies and their combinations.

\{Insert Table 2. Number of funds by category and SI generation Here\}

\subsection{Variable Description}

To measure the ESG risks (see Table 3), we use the Morningstar Portfolio Historical Sustainability Risk Score, as well as the Environmental, Social, and Governance Portfolio Risk Scores.

\{Insert Table 3. ESG attributes and Carbon Risk score by SI funds generations Here\}

The Morningstar Portfolio Sustainability Score is an asset-weighted average of Sustainalytics' company-level ESG Risk Score. The Sustainalytics' company-level ESG Risk Score measures the degree to which a company's economic value may be at risk driven by ESG factors. Morningstar Historical Sustainability Score is a weighted average of the trailing 12 months of Morningstar Portfolio Sustainability Scores. Historical portfolio scores are not equal-weighted; rather, more recent portfolios are weighted more heavily than older portfolios. Like the ESG Risk Scores, the Portfolio Sustainability Score is rendered on a 0-100 scale, where lower scores are better, using an asset-weighted average of all covered securities. To receive a Portfolio Sustainability Score, at least $67 \%$ of a portfolio's assets under management (long positions only) must have a company ESG Risk Rating. The percentage of assets under management of the covered securities is rescaled to $100 \%$ before calculating the Portfolio Sustainability Score.

Environmental, Social, and Governance Portfolio Scores are the asset-weighted average of the Company Environmental/ Social/ Governance Risk scores for the covered holdings in a portfolio. Company Environmental/Social/Governance Risk Scores from Sustainalytics measure the 
PREPRINT: Folqué, M., Escrig-OImedo, E., \& Corzo Santamaría, T. (2021). Sustainable development and financial system: Integrating ESG risks through sustainable investment strategies in a climate change context. Sustainable Development. DOI:

https://doi.org/10.1002/sd.2181

degree to which a company's economic value may be at risk driven by environmental/social/governance factors. The environmental/social/governance risk represents the unmanaged environmental/social/governance risk exposure after considering a company's management of such risks. The Environmental/Social/ Governance Risk Scores are displayed as a number between 0 and 100, though most scores range between 0 and 25 .

To measure the Carbon Risk (see Table 3), we use the Morningstar Portfolio Carbon Risk Score. It is the asset-weighted carbon-risk score of the equity or corporate-bond holdings in a portfolio (long positions only), averaged over the trailing 12 months. To calculate the portfolio carbonrisk scores, Morningstar uses Sustainalytics' company carbon-risk ratings, which indicate the risk that companies face from the transition to a low-carbon economy. Carbon risk rating is based on assessments across two dimensions: exposure and management. Exposure is a measure of the degree to which carbon risks are material across the company's supply chain, its own operations and in its products and services. Management is a measure of the ability and approach of the company to manage and reduce emissions and related carbon risks.

The sustainability risk scores provided by Morningstar seem to be aligned with the sustainability risk concept provided by the European Commission (EC, 2019).

\subsection{Statistical model.}

To analyze the differences among SI funds generations, we adopt a parametric ANOVA method where the dependent variables are the ESG risk scores and the carbon risk score; and the factor is the $\mathrm{SI}$ fund generation. The ANOVA test allows us to examine the mean differences between the four different groups of equity funds.

The ANOVA tests the null hypothesis that samples in all groups are drawn from populations with the same mean values. The ANOVA produces an F-statistic, the ratio of the variance calculated among means to the variance within the samples. Typically, the one-way ANOVA is used to test for differences among at least three groups, since a t-test can cover the two-group case.

The analysis of variance is based on three assumptions: normal distributed populations, homogeneity of variances, and independent samples (Moder \& Moder, 2010). Vargha \& Delaney (1998) recommend robust non-parametric tests in case of heterogeneous variances. KruskalWallis test is recommended in situations where homoscedasticity is violated.

Given the assumptions in which the ANOVA test relies on, our analysis follows these steps: First, we conduct a Kolmogorov-Smirnov test of normality; second, we test the homogeneity of variances based on the Levene statistic ${ }^{1}$. If there is homoscedasticity, we apply the parametric ANOVA one way to test which group is the most different. If the differences among SI funds

\footnotetext{
1 Available upon request.
} 
PREPRINT: Folqué, M., Escrig-OImedo, E., \& Corzo Santamaría, T. (2021). Sustainable development and financial system: Integrating ESG risks through sustainable investment strategies in a climate change context. Sustainable Development. DOI:

https://doi.org/10.1002/sd.2181

generations are statistically significant according to the F-statistic, we perform the Bonferroni and Tahmane post hoc tests to identify the differences between groups.

\section{Results}

This section first shows the results of the statistical tests and then discusses the main findings.

\subsection{ESG risks: Analysis of mean differences between SI funds generations.}

Table 4 displays that the results in terms of ESG risk scores differ according to SI funds generations; that is, there is a statistical difference between $\mathrm{SI}$ funds that only apply negative filters and funds that apply more advanced SI strategies on all the ESG risk scores measured: Historical Sustainability risk score, Environmental Risk score, Social risk score, and Governance risk score.

\{Insert Table 4. ANOVA to test the differences in means between SI funds generations in terms of ESG risk scores Here\}

We apply two post hoc tests to identify which groups are different between them. We use Bonferroni if equal variances are assumed and Tamhane if they are not, and we obtain similar results. Both tests show that there are statistically significant differences between the means of the Historical Sustainability Risk, Environmental Risk, Social Risk and Governance Risk scores of Generation 1 vs. Generation 2, Generation 3, Generation 4 and Generation 5. They also show significant differences between the average Portfolio Governance Score between Generation 3 and Generation 5. In table 5, we present the Bonferroni test results ${ }^{2}$.

\{Insert Table 5. POST HOC Tests. Multiple Comparisons Here\}

\subsection{Carbon Risk: Analysis of mean differences between SI funds generations.}

As Table 6 shows, there are statistically significant differences between $\mathrm{SI}$ funds generations on their carbon risk score. This result highlights that there is a statistical difference in the average carbon risk score between the first SI funds generation and funds that apply more advanced SI strategies. Therefore, we have to apply the post hoc tests to identify which generations are different between them.

\{Insert Table 6. ANOVA to test the differences in means between SI funds generations in terms of carbon risk scores Here\}

\footnotetext{
${ }^{2}$ Tahmane test results available upon request.
} 
PREPRINT: Folqué, M., Escrig-Olmedo, E., \& Corzo Santamaría, T. (2021). Sustainable development and financial system: Integrating ESG risks through sustainable investment strategies in a climate change context. Sustainable Development. DOI:

https://doi.org/10.1002/sd.2181

We apply two post hoc tests (Table 7) to identify which groups are different between them. We use Bonferroni if equal variances are assumed and Tamhane if they are not, and we obtain similar results. Both tests show that there are statistically significant differences between the means of Carbon Risk score of Generation 1 vs. Generation2, Generation 3, Generation 4 and Generation 5. In table 7, we present the Bonferroni test results ${ }^{3}$.

\{Insert Table 7. POST HOC Tests. Multiple Comparisons Here\}

\section{Discussion}

Table 8 summarizes the statistically significant differences between the SI funds generations. The results show that the most different $\mathrm{SI}$ fund generation is the first, which includes funds that only apply negative screening, which we consider as a non-advanced strategy. This first generation shows statistically significant different means in every variable analyzed compared with the rest of the four SI Funds generations.

Generation 1 of SI Funds shows on average statistically significant (at $p<0.01$ ) ESG risks in aggregate as measured by the Historical Sustainability Risk Score and in Governance Risk Score compared with Generations 2, 3, 4, and 5. Generation 1 also shows a statistically significant mean (at $p<0.01$ ) in Environmental Risk Score than Generations 4 and 5 and at $p<0.05$ with Generations 2 and 3. Finally, regarding the ESG attributes, Generation 1 shows statistically significant (at $p<0.01$ ) Social Risk Score compared with Generations 2, 3, and 5 and at $p<0.05$ with Generation 4.

Regarding the variable Carbon Risk Score, again, Generation 1 of SI Funds shows a statistically significant mean (at $\mathrm{p}<0.01$ ) compared to Generations $2,3,4$, and 5

\section{\{Insert Table 8. Summary of statistically significant differences of means between SI funds} generations Here\}

These results show that, on average, first SI funds generation, the ones that only apply negative filters, achieve higher ESG risk scores whether in aggregated, as measured in terms of Historical Sustainability Score, as in each of the ESG risk domains: Environmental, Social and Governance, compared to the four more advanced Generations of SI funds. The first generation of SI funds also shows a higher Carbon Risk score.

It is worth mentioning that, as shown in Table 3, Generation 5 that encompasses impact funds, achieves the lowest Governance Risk and Carbon Risk scores, and Generation 5 that includes funds with policies of stewardship obtains the lowest Environmental risk score. Regarding the Social Risk, we find the lowest scores in Generation 2 (positive screening) and Generation 3 (a

\footnotetext{
3 Tahmane test results available upon request.
} 
PREPRINT: Folqué, M., Escrig-OImedo, E., \& Corzo Santamaría, T. (2021). Sustainable development and financial system: Integrating ESG risks through sustainable investment strategies in a climate change context. Sustainable Development. DOI:

https://doi.org/10.1002/sd.2181

combination of positive and negative screening). However, there are no statistically significant differences between the means of SI Funds Generations with advanced SI strategies, except between the third and five Generations in Governance Risk Score where impact funds show lower risk.

Therefore, Hypothesis $\mathrm{H} 1$ is accepted; funds with advanced SI strategies exhibit lower ESG risks, since the means of the four ESG risk scores analyzed (Historical Sustainability Risk Score, Environmental Risk Score, Social Risk Score, and Governance Risk Score) show lower ESG risks in all the four advanced SI Generations vs. SI Generation 1. The results are in line with the branch of recent literature that considers simple negative screening as an outdated or non-advanced practice versus forward-looking ESG analysis focused on assessing the materiality of nontraditional data to determine which companies are best fit to face sustainability risks (Townsend, 2020); and maintain that ESG investing is fundamentally different from screening out sin stocks (Alessandrini \& Jondeau, 2020).

Finally, from the evidence presented, $\mathrm{H} 2$ is accepted. Funds with advanced $\mathrm{SI}$ strategies exhibit lower carbon risk since the mean of the Carbon Risk Score of Generation 1 is statistically significantly higher than the means of Generations 2, 3, 4, and 5 . This outcome underscores the effort that, according to Schoenmaker \& Van Tilburg (2016), some financial institutions have started to do by setting targets to reduce carbon emissions in their lending and investments. The result could also reflect the growing awareness of more advanced SI fund managers about the consequences of exposure to the so-called carbon bubble (Schoenmaker \& Van Tilburg, 2016; Weyzig et al. 2014, Cheema-Fox et al., 2020), considering that more advanced SI strategies allow better management of portfolio carbon risks

Although negative screening is still the strategy with more assets under management, these findings align with the industry gradual change to more advanced SI strategies (Eurosif, 2018). This change should be expected in a market with more available risk data (heterogeneous but available), where ESG and Carbon risks are starting to be considered risk factors in the construction of investment portfolios (Maiti, 2020).

\section{Conclusion}

Sustainable investment is on its way to becoming a paradigm shift in the financial world. Originally, SI was about how to avoid harm, excluding specific sectors and companies. It gradually shifted to try to benefit different stakeholders in a sector. Nevertheless, after the launch of the SDGs (2015) and the Paris agreement (2016), it should be something more; SI can be part of the solution, a bridge between the financial sector and sustainable development.

The challenges of climate change and the risks and opportunities of the transition to a decarbonized economy are already part of the European legislation. The release of the European Commission's Action Plan on Financing Sustainable Growth in 2018 has entirely changed the 
PREPRINT: Folqué, M., Escrig-OImedo, E., \& Corzo Santamaría, T. (2021). Sustainable development and financial system: Integrating ESG risks through sustainable investment strategies in a climate change context. Sustainable Development. DOI:

https://doi.org/10.1002/sd.2181

landscape of SI in the continent. The Taxonomy, the regulation on climate benchmarks (CTB and $P A B$ ), and the Sustainable Finance Disclosure Regulation (SFDR) directly affect the asset management industry.

In this new regulatory environment, EU managers and managers of funds distributed in the EU will be required to incorporate ESG and non-financial risks into their risk management frameworks, and all products will be assessed for potential ESG risks, even if they are not explicitly ESG products. Sustainability risks are now the focus, and they have to be measurable and comparable.

Despite these radical changes and milestones in the SI world, there are very few academic studies on SI funds that evaluate how they manage ESG risks according to the different SI strategies they apply. For this reason, in contrast to previous literature, our aim with this study is to measure the ESG risk exposure of ESG portfolios managed with different SI strategies within a complete framework consistent with global challenges that consider sustainability and carbon risks. But, which SI strategy achieves the lowest sustainability and carbon risks and therefore facilitates the integration of sustainability into the financial market, contributing to sustainable development?

The results show that, on average, the funds managed according to advanced SI strategies achieve statistically significant lower ESG risks in terms of all the four ESG risks variables analyzed: the Historical Sustainability Risk Score, the Environmental Risk Score, the Social Risk Score, and the Governance Risk Score compared to the funds that only applies negative filters (first SI funds generation). This first generation of SI funds also shows a statistically significant Carbon Risk score than the four advanced strategies.

The above findings confirm that the transition to a lower-carbon economy and the 2030 sustainability agenda demands more advanced investment strategies that consider which ESG criteria and extra-financial risks could be more significant. The oldest and most basic SI practice was a starting point when there was a lack of data, but as we have shown, it is not the bestfitted strategy to reduce ESG and carbon risks of the investment portfolios. Negative screening is still the most used SI strategy, but if the fund management industry wants to make a more profound and broader contribution to sustainability and climate change mitigation, managers stuck with this SI strategy should consider more advanced SI strategies. Strategies that not only avoid specific sectors but focus on activities and industries that can have a positive and measurable effect and impact on sustainability, contributing either to the mitigation of climate change or to achieving specific SDGs, or both.

In terms of competitive advantage, if investment funds' performance is analyzed and compared from a complete framework that includes ESG attributes and climate change scores, many asset management companies would be compelled to evolving in their SI practices. This advance could be relevant in terms of risk control and fiduciary duty. Moreover, by following these advanced 
PREPRINT: Folqué, M., Escrig-OImedo, E., \& Corzo Santamaría, T. (2021). Sustainable development and financial system: Integrating ESG risks through sustainable investment strategies in a climate change context. Sustainable Development. DOI:

https://doi.org/10.1002/sd.2181

strategies, those investment funds will better comply with the regulations soon to be imposed in the Eurozone regarding Taxonomy and Disclosure.

The COVID-19 pandemic has raised awareness of ESG issues and has prompt action towards a different economic recovery model after the downturn, a sustainable one. In Europe, the Just Transition fund (up to 40 EUR billion) and the European Recovery and Resilience Facility with EUR 310 billion of grants and 250 billion of loans have sustainability and low carbon transition at its core (PWC, 2020). The asset management industry should be ready to be part of this opportunity. To make a significant contribution to a sustainable recovery, asset managers need advanced investment strategies. Strategies or a combination of them, that could effectively tackle SDGs' achievement, as we see in some new recently launched Impact Funds (SI Generation5), or the will to influence their investee companies through engagement (SI Generation 4), or the access to analysis and data to design lower ESG risks portfolios (SI Generations 2, 3,4, and 5).

In sum, this study contributes to the previous literature in achieving a more profound knowledge about the different SI strategies' different outcomes, not based on financial performance but widening the focus to ESG and Carbon risks. It may also be useful for the asset management companies if it helps increase the awareness of the crucial importance of moving forward in $\mathrm{SI}$ practice in terms of fiduciary duty, legal compliance, competitive advantage, and contribution to sustainable development.

The method employed in this study could have limitations. We are aware that given the documented divergence of ESG ratings (Gibson et al., 2020) choosing only one database for this study may have shortcomings. We rely on Morningstar data based on Sustainalytics methodology, and data from different suppliers could show other outcomes. Moreover, Sustainalytics relies on self-disclosed data by companies, which could have potential drawbacks. Second, given the recent launch of Morningstar funds' sustainability risk scores, our analysis period is forcibly short. Third, our study is based on large-cap funds invested in different regional areas but focuses on vehicles registered and or distributed in Europe, which could make our results less generalizable. Thus, future research in advanced SI practices could focus on different data suppliers, players, and assets, encompassing more extended periods. 
PREPRINT: Folqué, M., Escrig-Olmedo, E., \& Corzo Santamaría, T. (2021). Sustainable development and financial system: Integrating ESG risks through sustainable investment strategies in a climate change context. Sustainable Development. DOI:

https://doi.org/10.1002/sd.2181

\section{References}

Alessandrini, F., \& Jondeau, E. (2020). Optimal Strategies for ESG Portfolios. Swiss Finance Institute Research Paper, (No. 20-21). https://doi.org/10.2139/ssrn.3578830

Ashwin Kumar, N. C., Smith, C., Badis, L., Wang, N., Ambrosy, P., \& Tavares, R. (2016). ESG factors and risk-adjusted performance: a new quantitative model. Journal of Sustainable Finance and Investment, 6(4), 292-300. http://doi.org/10.1080/20430795.2016.1234909

Barnett, M. L., \& Salomon, R. M. (2006). Beyond dichotomy: The curvilinear relationship between social responsibility and financial performance. Strategic Management Journal, 27, 1101-1122. http://doi.org/10.1002/smj.557

Bauer, R., Koedijk, K., \& Otten, R. (2002). International evidence on Ethical Fund Performance and Investment Style. Centre for Economic Policy Research, (July), 1-28.

Berg, F., Koelbel, J. F., \& Rigobon, R. (2019). Aggregate Confusion: The Divergence of ESG Ratings. MIT Sloan School of Management. https://doi.org/10.2139/ssrn.3438533

Bertolotti, A. (2020). Effectively managing risks in an esg portfolio. Journal of Risk Management in Financial Institutions, 13(3), 202-211.

Boiral, O., Talbot, D., \& Brotherton, M. C. (2020). Measuring sustainability risks: A rational myth? Business Strategy and the Environment, (July 2019), 1-15. https://doi.org/10.1002/bse.2520

Bolton, P., \& Kacperczyk, M. T. (2019). Do Investors Care about Carbon Risk? National Bureau of Economic Research. https://doi.org/10.2139/ssrn.3398441

Bollen, N. 2007. 'Mutual fund attributes and investor behavior'. Journal of Financial and Quantitative Analysis, 683-708.

Bradford, M., Earp, J. B., \& Williams, P. F. (2017). Understanding sustainability for socially responsible investing and reporting. Journal of Capital Markets Studies, 1(1), 10-35. http://doi.org/10.1108/jcms-10-2017-005

Bugg-Levine, A., \& Emerson, J. (2011). Impact investing: Transforming how we make money while making a difference. Innovations: Technology, Governance, Globalization, 6(3), 9-18.

Busch, T., Bauer, R., \& Orlitzky, M. (2015). Sustainable Development and Financial Markets: Old Paths and New Avenues. Business \& Society, 55(3), 303-329.

Busch, T., \& Friede, G. (2018). The robustness of the corporate social and financial performance relation: A second-order meta-analysis. Corporate Social Responsibility and Environmental Management, 25(4), 583-608. http://doi.org/10.1002/csr.1480

Capelle-Blancard, G., \& Monjon, S. (2012). A European Review Trends in the literature on socially responsible investment : looking for the keys under the lamppost. Business Ethics, 21(3), 239-250. http://doi.org/10.1111/j.1467-8608.2012.01658.x

Capelle-Blancard, G., \& Monjon, S. (2014). The Performance of Socially Responsible Funds : Does the Screening Process Matter? European Financial Management, 20(3), 494-520. http://doi.org/10.1111/j.1468-036X.2012.00643.x

Carè, R., \& Wendt, K. (2018). Social Impact Investing Beyond the SIB. Palgrave Macmillan, Cham https://doi.org/10.1007/978-3-319-78322-2

Cheema-Fox, A., Laperla, B. R., Serafeim, G., Turkington, D., \& Wang, H. S. (2020). Decarbonizing Everything : Climate Data, Industry Returns, and Portfolio Construction, 1-49. Working Paper. Harvard Business School.

Demerens, F., Géraud, B., Paré, J.-L., \& Rédis, J. (2014). Do European Mid-cap firms disclose enough non-financial, specifically CSR-related information to their stakeholders? Gestion 2000 (Vol. 31). https://doi.org/10.3917/g2000.311.0179

Dimson, E., Karakaş, O., \& Li, X. (2015). Active Ownership. Review of Financial Studies, 28(12), 3225-3268. https://doi.org/10.1093/rfs/hhv044 
PREPRINT: Folqué, M., Escrig-Olmedo, E., \& Corzo Santamaría, T. (2021). Sustainable development and financial system: Integrating ESG risks through sustainable investment strategies in a climate change context. Sustainable Development. DOI:

https://doi.org/10.1002/sd.2181

Drei, A., Le Guenedal, T., Lepetit, F., Mortier, V., Roncalli, T., \& Sekine, T. (2020). ESG Investing in Recent Years: New Insights from Old Challenges. Amundi Discussion Paper, 42(February 2020). https://doi.org/10.2139/ssrn.3683469

European Commission (2019)

https://eurlex.europa.eu/legalcontent/EN/TXT/PDF/?uri=CELEX:32019R2088\&from=EN

Eccles, R. G. (2015). Corporate and Integrated Reporting : A Functional Perspective. Chapter in Stewardship of the Future, Edited by Ed Lawler, Sue Mohrman, and James O'Toole, Greenleaf, 2015.

Eccles, R. G., \& Serafeim, G. (2011). Market Interest in Nonfinancial Information. Journal of Applied Corporate Finance, 23(4), 113-127.

Eccles, R. G., \& Serafeim, G. (2013). The Performance Frontier. Harvard Business Review, 91(5), 50-60.

Escrig-Olmedo, E., Rivera-Lirio, J. M., Muñoz-Torres, M. J., \& Fernández-Izquierdo M. Á. (2017). Integrating multiple ESG investors' preferences into sustainable investment: A fuzzy multicriteria methodological approach. Journal of cleaner production, 162, 1334-1345.

Escrig-Olmedo, E., Fernández-Izquierdo, M. ángeles, Ferrero-Ferrero, I., Rivera-Lirio, J. M., \& Muñoz-Torres, M. J. (2019). Rating the raters: Evaluating how ESG rating agencies integrate sustainability principles. Sustainability, 11(3). https://doi.org/10.3390/su11030915

Eurosif. (2016). European SRI Study 2016. Eurosif, European SRI study.

Eurosif. (2018). European SRI study 2018. Eurosif, European SRI study. Retrieved from http://scholar.google.com/scholar?hl=en\&btnG=Search\&q=intitle:European+SRI+Study\# 8

Gangi, F., \& Varrone, N. (2018). Screening activities by socially responsible funds: A matter of agency? Journal of Cleaner Production, 197, 842-855. http://doi.org/10.1016/j.jclepro.2018.06.228

Gibson, R., Krueger, P., Riand, N., \& Schmidt, P. S. (2020). ESG rating disagreement and stock returns. ECGI Working Paper Series in Finance ESG (Vol. Working Pa).

GIIN. (2018). Core Characteristics of Impact Investing, 2.

Global Sustainable Investment Review. (2019). 2018 Global Sustainable Investment Review. Retrieved from http://www.gsi-alliance.org/wpcontent/uploads/2019/03/GSIR_Review2018.3.28.pdf

Görgen, M., Nerlinger, M., \& Wilkens, M. (2017). Carbon Risk. SSRN, 1-59. https://doi.org/10.2139/ssrn.2930897

Grantham Research Institute on Climate Change, LSE, \& Initiative for Responsible Investment at the Harvard Kennedy School. (2018). Climate change and the just transition A guide for investor action. Retrieved from www.Ise.ac.uk/GranthamInstitute/

Harnisch, J., Enting, K., \& Ruffing, M. (2014). Linking climate targets and investment portfolios: Exploring the utility of cross-sectoral emission intensity indicators. Carbon Management, 5(5-6), 543-555. http://doi.org/10.1080/17583004.2015.1040948

Henriksson, R., Livnat, J., Pfeifer, P., \& Stumpp, M. (2019). Integrating ESG in Portfolio Construction. The Journal of Portfolio Management, 45(4), 67-81. https://doi.org/10.3905/jpm.2019.45.4.067

Hoepner, A. G. F., Oikonomou, I., Sautner, Z., Starks, L. T., \& Zhou, X. (2019). ESG Shareholder Engagement and Downside Risk. AFA 2018 Paper, European Corporate Governance Institute - Finance Working Paper, No. 671/20(April). https://doi.org/10.2139/ssrn.2874252

Hübel, B., \& Scholz, H. (2020). Integrating sustainability risks in asset management: the role of ESG exposures and ESG ratings. Journal of Asset Management, 21(1), 52-69. https://doi.org/10.1057/s41260-019-00139-z

Ibikunle, G., \& Steffen, T. (2017). European Green Mutual Fund Performance: A Comparative 
PREPRINT: Folqué, M., Escrig-Olmedo, E., \& Corzo Santamaría, T. (2021). Sustainable development and financial system: Integrating ESG risks through sustainable investment strategies in a climate change context. Sustainable Development. DOI:

https://doi.org/10.1002/sd.2181

Analysis with their Conventional and Black Peers. Journal of Business Ethics, 145(2), 337355. http://doi.org/10.1007/s10551-015-2850-7

IPCC (2018). Special Report Global Warming of $1.5^{\circ} \mathrm{C}$. www.ipcc.ch

Jansson, M., \& Biel, A. (2011). Motives to engage in sustainable investment: A comparison between institutional and private investors. Sustainable Development, 19(2), 135-142. http://doi.org/10.1002/sd.512

Juravle, C., \& Lewis, A. (2008). Identifying impediments to SRI in Europe: a review of the practitioner and academic literature. Business Ethics, 17(3), 285-310.

Kempf, A., \& Osthoff, P. (2007). The effect of socially responsible investing on portfolio performance. European Financial Management, 13(5), 908-922.

Kölbel, J. F., Heeb, F., Paetzold, F., \& Busch, T. (2020). Can sustainable investing save the world? Reviewing the mechanisms of investor impact. Organization \& Environment, 33(4), 554574.

Krüger, P., Sautner, Z., \& Starks, L. T. (2018). The Importance of Climate Risks for Institutional Investors. Swiss Finance Institute Research Paper Series, N¹8-58.

Leite, P., \& Cortez, M. C. (2014). Style and performance of international socially responsible funds in Europe. Research in International Business and Finance, 30(1), 248-267. http://doi.org/10.1016/j.ribaf.2013.09.007

Louche, C., Busch, T., Crifo, P., \& Marcus, A. (2019). Financial Markets and the Transition to a Low-Carbon Economy: Challenging the Dominant Logics. Organization and Environment, 32(1), 3-17. http://doi.org/10.1177/1086026619831516

Maiti, M. (2020). Is ESG the succeding risk factor? Journal of Sustainable Finance and Investment, 1-15. https://doi.org/10.1080/20430795.2020.1723380

Matallín-Sáez, J. C., Soler-Domínguez, A., Tortosa-Ausina, E., \& de Mingo-López, D. V. (2019). Ethical strategy focus and mutual fund management: Performance and persistence. Journal of Cleaner Production, 213, 618-633. http://doi.org/10.1016/j.jclepro.2018.12.130

Moder, K., \& Moder, K. (2010). Alternatives to F-Test in One Way ANOVA in case of heterogeneity of variances (a simulation study). Psychological Test and Assessment Modeling, 52(4), 343-353.

Nofsinger, J., \& Varma, A. (2014). Socially responsible funds and market crises. Journal of Banking and Finance, 48(509), 180-193. http://doi.org/10.1016/j.jbankfin.2013.12.016

Ortas, E., Moneva, J. M., Burritt, R., \& Tingey-Holyoak, J. (2014). Does Sustainability Investment Provide Adaptive Resilience to Ethical Investors? Evidence from Spain. Journal of Business Ethics, 124, 297-309. http://doi.org/10.1007/s10551-013-1873-1

PWC. (2017). The SDG Investment Case. Retrieved from

https://www.unpri.org/download_report/42251

PWC. (2020). PWC-ESG Report. The growth opportunity of the century. Retrieved from www.pwc.lu/esg-report

Renneboog, L., Ter Horst, J., \& Zhang, C. (2008). The price of ethics and stakeholder governance: The performance of socially responsible mutual funds. Journal of Corporate Finance, 14(3), 302-322. http://doi.org/10.1016/j.jcorpfin.2008.03.009

Revelli, C. (2017). Socially responsible investing (SRI): From mainstream to margin? Research in International Business and Finance, 39, 711-717. http://doi.org/10.1016/j.ribaf.2015.11.003

Ritchie, J., \& Dowlatabadi, H. (2015). Divest from the Carbon Bubble? Reviewing the Implications and Limitations of Fossil Fuel Divestment for Institutional Investors. Review of Economics and Finance, 5(2), 59-80. Retrieved from http://blogs.ubc.ca/dowlatabadi/welcome/

Saadaoui, K., \& Soobaroyen, T. (2018). An analysis of the methodologies adopted by CSR rating 
PREPRINT: Folqué, M., Escrig-Olmedo, E., \& Corzo Santamaría, T. (2021). Sustainable development and financial system: Integrating ESG risks through sustainable investment strategies in a climate change context. Sustainable Development. DOI:

https://doi.org/10.1002/sd.2181

agencies. Sustainability Accounting, Management and Policy Journal, 9(1), 43-62. https://doi.org/10.1108/SAMPJ-06-2016-0031

Sandberg, J. (2011). Socially Responsible Investment and Fiduciary Duty: Putting the Freshfields Report into Perspective. Journal of Business Ethics, 101(1), 143-162. http://doi.org/10.1007/s10551-010-0714-8

Schoenmaker, D., \& Van Tilburg, R. (2016). What Role for Financial Supervisors in Addressing Environmental Risks? Comparative Economic Studies, 58(3), 409-429. http://doi.org/10.1057/s41294-016-0002-4

Semenova, N., \& Hassel, L. G. (2015). On the Validity of Environmental Performance Metrics. Journal of Business Ethics, 132(2), 249-258. https://doi.org/10.1007/s10551-014-2323-4

Silva, F., \& Cortez, M. C. (2016). The performance of US and European green funds in different market conditions. Journal of Cleaner Production, 135, 558-566. http://doi.org/10.1016/j.jclepro.2016.06.112

Townsend, B. (2020). From SRI to ESG: The Origins of Socially Responsible and Sustainable Investing. The Journal of Impact and ESG Investing, 1(1).

Trinks, A., Scholtens, B., Mulder, M., \& Dam, L. (2018). Fossil Fuel Divestment and Portfolio Performance. Ecological Economics, 146, 740-748. http://doi.org/10.1016/j.ecolecon.2017.11.036

Trinks, P. J., \& Scholtens, B. (2017). The Opportunity Cost of Negative Screening in Socially Responsible Investing. Journal of Business Ethics, 140(2), 193-208. http://doi.org/10.1007/s10551-015-2684-3

Van Duuren, E., Plantinga, A., \& Scholtens, B. (2016). ESG Integration and the Investment Management Process: Fundamental Investing Reinvented. Journal of Business Ethics, 138(3). http://doi.org/10.1007/s10551-015-2610-8

Vargha, A., \& Delaney, H. D. (1998). The Kruskal-Wallis Test and Stochastic Homogeneity. Journal of Educational and Behavioral Statistics, 23(2), 170-192. http://doi.org/10.3102/10769986023002170

von Wallis, M., \& Klein, C. (2015). Ethical requirement and financial interest: a literature review on socially responsible investing. Business Research, 8(1), 61-98. http://doi.org/10.1007/s40685-014-0015-7

Weber, O., Diaz, M., \& Schwegler, R. (2012). Corporate Social Responsibility of the Financial Sector - Strengths, Weaknesses and the Impact on Sustainable Development. Sustainable Development, 335(May 2012), 321-335. https://doi.org/10.1002/sd.1543

Weyzig, F., Kuepper, B., Van Gelder, J. W., \& Van Tilburg, R. (2014). The Price of Doing Too Little Too Late. Green New Deal Series, 11, 61. Retrieved from www.gef.eu

Widyawati, L. (2020). A systematic literature review of socially responsible investment and environmental social governance metrics. Business Strategy and the Environment, 29(2), 619-637. https://doi.org/10.1002/bse.2393 
PREPRINT: Folqué, M., Escrig-Olmedo, E., \& Corzo Santamaría, T. (2021). Sustainable development and financial system: Integrating ESG risks through sustainable investment strategies in a climate change context. Sustainable Development. DOI:

https://doi.org/10.1002/sd.2181

Tables

Table 1. SI generations according to their strategies or aggregated strategies

\begin{tabular}{|c|c|c|c|c|}
\hline $\begin{array}{l}\text { 1st Generation } \\
\text { SI Strategies }\end{array}$ & $\begin{array}{l}\text { 2nd Generation } \\
\text { SI Strategies }\end{array}$ & $\begin{array}{l}\text { 3rd Generation } \\
\text { SI Strategies }\end{array}$ & $\begin{array}{l}\text { 4th Generation } \\
\text { SI Strategies }\end{array}$ & $\begin{array}{l}\text { 5th Generation } \\
\text { SI Strategies }\end{array}$ \\
\hline $\begin{array}{l}\text { Negative } \\
\text { screening }\end{array}$ & $\begin{array}{l}\text { Positive } \\
\text { screening }\end{array}$ & $\begin{array}{c}\text { Negative } \\
\text { screening } \\
+ \\
\text { Positive screening }\end{array}$ & $\begin{array}{c}\text { Negative screening } \\
\text { or/and } \\
\text { Positive screening } \\
+ \\
\text { Engagement }\end{array}$ & $\begin{array}{c}\text { Impact } \\
\text { Investment }\end{array}$ \\
\hline
\end{tabular}

Source: Own creation based on Renneboog et al. (2008), Eurosif (2018) and GSIA (2019).

Table 2. Number of funds by category and SI generation

\begin{tabular}{|c|c|c|c|c|c|c|c|}
\hline \multirow[b]{2}{*}{ Global Category } & \multicolumn{5}{|c|}{ SI Generation } & \multirow{2}{*}{ Total } & \multirow{2}{*}{ Percentage } \\
\hline & First & Second & Third & Fourth & Fifth & & \\
\hline Europe Equity Large Cap & 26 & 59 & 70 & 44 & 36 & 235 & $39.97 \%$ \\
\hline Global Emerging Markets & 16 & 11 & 12 & 11 & 7 & 57 & $9.69 \%$ \\
\hline Global Equity Large Cap & 37 & 45 & 49 & 31 & 75 & 237 & $40.31 \%$ \\
\hline US Equity Large Cap & 15 & 6 & 16 & 14 & 8 & 59 & $10.03 \%$ \\
\hline Total & 94 & 121 & 147 & 100 & 126 & 588 & \\
\hline Percentage & $15.99 \%$ & $20.58 \%$ & $25.00 \%$ & $17.01 \%$ & $21.43 \%$ & & $100 \%$ \\
\hline
\end{tabular}

Table 3. ESG attributes and Carbon Risk score by SI funds generations.

\begin{tabular}{|c|c|c|c|c|c|c|c|c|c|c|}
\hline \multirow[t]{2}{*}{ SI Generation } & \multicolumn{2}{|c|}{$\begin{array}{c}\text { Historical } \\
\text { Sustainability Risk } \\
\text { Score }\end{array}$} & \multicolumn{2}{|c|}{$\begin{array}{c}\text { Environmental Risk } \\
\text { Score }\end{array}$} & \multicolumn{2}{|c|}{$\begin{array}{l}\text { Social Risk } \\
\text { Score }\end{array}$} & \multicolumn{2}{|c|}{$\begin{array}{l}\text { Governance } \\
\text { Risk Score }\end{array}$} & \multicolumn{2}{|c|}{$\begin{array}{l}\text { Carbon Risk } \\
\text { Score }\end{array}$} \\
\hline & Mean & STD & Mean & STD & Mean & STD & Mean & STD & Mean & STD \\
\hline First & 23.70 & 2.06 & 4.48 & 0.96 & 9.30 & 1.07 & 8.06 & 0.86 & 8.63 & 2.78 \\
\hline Second & 21.82 & 1.83 & 4.12 & 0.76 & 8.74 & 1.16 & 7.68 & 0.71 & 6.74 & 2.03 \\
\hline Third & 21.84 & 2.01 & 4.15 & 0.90 & 8.74 & 1.07 & 7.71 & 0.69 & 6.94 & 2.00 \\
\hline Fourth & 21.91 & 1.75 & 3.90 & 0.77 & 8.84 & 1.14 & 7.64 & 0.72 & 6.45 & 1.83 \\
\hline Fifth & 21.82 & 1.72 & 4.06 & 0.84 & 8.76 & 1.09 & 7.45 & 0.84 & 6.30 & 1.99 \\
\hline
\end{tabular}

Table 4. ANOVA to test the differences in means between SI funds generations in terms of ESG risk scores.

\begin{tabular}{llccccc}
\hline & & Sum of Squares & df & Mean Square & F & Sig. \\
\hline Historical & Between Groups & 272.180 & 4 & 68.045 & 19.260 & $0.000^{* * *}$ \\
Sustainability Risk & & & & & & \\
Score & & & & & \\
& Within Groups & 2059.687 & 583 & 3.533 & & \\
& Total & 2331.867 & 587 & & & \\
\hline
\end{tabular}


PREPRINT: Folqué, M., Escrig-Olmedo, E., \& Corzo Santamaría, T. (2021). Sustainable development and financial system: Integrating ESG risks through sustainable investment strategies in a climate change context. Sustainable Development. DOI:

https://doi.org/10.1002/sd.2181

\begin{tabular}{|c|c|c|c|c|c|c|}
\hline \multirow{3}{*}{$\begin{array}{l}\text { Environmental Risk } \\
\text { Score }\end{array}$} & Between Groups & 17.453 & 4 & 4.363 & 6.091 & $0.000^{* * *}$ \\
\hline & Within Groups & 417.606 & 583 & 0.716 & & \\
\hline & Total & 435.060 & 587 & & & \\
\hline \multirow[t]{3}{*}{ Social Risk Score } & Between Groups & 23.415 & 4 & 5.854 & 4.801 & $0.001^{* * *}$ \\
\hline & Within Groups & 710.891 & 583 & 1.219 & & \\
\hline & Total & 734.306 & 587 & & & \\
\hline \multirow{3}{*}{$\begin{array}{l}\text { Governance Risk } \\
\text { Score }\end{array}$} & Between Groups & 20.025 & 4 & 5.006 & 8.671 & $0.000 * * *$ \\
\hline & Within Groups & 336.598 & 583 & 0.577 & & \\
\hline & Total & 356.623 & 587 & & & \\
\hline
\end{tabular}

*** The mean difference is significant at the 0.01 level

Table 5. POST HOC Tests. Multiple Comparisons

\begin{tabular}{|c|c|c|c|c|c|c|c|}
\hline \multicolumn{3}{|l|}{ Dependent Variable } & \multirow{2}{*}{$\begin{array}{c}\text { Mean } \\
\text { Difference (I-J) }\end{array}$} & \multirow[t]{2}{*}{ Std. Error } & \multirow[t]{2}{*}{ Sig. } & \multicolumn{2}{|c|}{ 95\% Confidence Interval } \\
\hline & & & & & & Lower Bound & Upper Bound \\
\hline \multirow{20}{*}{$\begin{array}{l}\text { Historical Bonferroni } \\
\text { Sustainability Risk } \\
\text { Score }\end{array}$} & First & Second & $1,87789^{*}$ & 0.258 & 0.000 & 1.150 & 2.606 \\
\hline & & Third & $1,85940^{*}$ & 0.248 & 0.000 & 1.160 & 2.559 \\
\hline & & Fourth & $1,79031^{*}$ & 0.270 & 0.000 & 1.029 & 2.551 \\
\hline & & Fifth & $1,87767^{*}$ & 0.256 & 0.000 & 1.156 & 2.599 \\
\hline & Second & First & $-1,87789^{*}$ & 0.258 & 0.000 & -2.606 & -1.150 \\
\hline & & Third & -0.01849 & 0.231 & 1.000 & -0.669 & 0.632 \\
\hline & & Fourth & -0.08759 & 0.254 & 1.000 & -0.803 & 0.628 \\
\hline & & Fifth & -0.00023 & 0.239 & 1.000 & -0.674 & 0.674 \\
\hline & Third & First & $-1,85940^{*}$ & 0.248 & 0.000 & -2.559 & -1.160 \\
\hline & & Second & 0.01849 & 0.231 & 1.000 & -0.632 & 0.669 \\
\hline & & Fourth & -0.06909 & 0.244 & 1.000 & -0.756 & 0.617 \\
\hline & & Fifth & 0.01827 & 0.228 & 1.000 & -0.625 & 0.661 \\
\hline & Fourth & First & $-1,79031^{*}$ & 0.270 & 0.000 & -2.551 & -1.029 \\
\hline & & Second & 0.08759 & 0.254 & 1.000 & -0.628 & 0.803 \\
\hline & & Third & 0.06909 & 0.244 & 1.000 & -0.617 & 0.756 \\
\hline & & Fifth & 0.08736 & 0.252 & 1.000 & -0.622 & 0.797 \\
\hline & Fifth & First & $-1,87767^{*}$ & 0.256 & 0.000 & -2.599 & -1.156 \\
\hline & & Second & 0.00023 & 0.239 & 1.000 & -0.674 & 0.674 \\
\hline & & Third & -0.01827 & 0.228 & 1.000 & -0.661 & 0.625 \\
\hline & & Fourth & -0.08736 & 0.252 & 1.000 & -0.797 & 0.622 \\
\hline \multirow{18}{*}{$\begin{array}{l}\text { Environmental Risk Bonferroni } \\
\text { Score }\end{array}$} & First & Second & $0,35951^{*}$ & 0.116 & 0.021 & 0.032 & 0.687 \\
\hline & & Third & $0,33312^{*}$ & 0.112 & 0.030 & 0.018 & 0.648 \\
\hline & & Fourth & $0,58086^{*}$ & 0.122 & 0.000 & 0.238 & 0.923 \\
\hline & & Fifth & $0,41714^{*}$ & 0.115 & 0.003 & 0.092 & 0.742 \\
\hline & Second & First & $-0,35951^{*}$ & 0.116 & 0.021 & -0.687 & -0.032 \\
\hline & & Third & -0.02639 & 0.104 & 1.000 & -0.319 & 0.266 \\
\hline & & Fourth & 0.22136 & 0.114 & 0.534 & -0.101 & 0.544 \\
\hline & & Fifth & 0.05763 & 0.108 & 1.000 & -0.246 & 0.361 \\
\hline & Third & First & $-0,33312^{*}$ & 0.112 & 0.030 & -0.648 & -0.018 \\
\hline & & Second & 0.02639 & 0.104 & 1.000 & -0.266 & 0.319 \\
\hline & & Fourth & 0.24774 & 0.110 & 0.243 & -0.061 & 0.557 \\
\hline & & Fifth & 0.08402 & 0.103 & 1.000 & -0.206 & 0.374 \\
\hline & Fourth & First & $-0,58086^{*}$ & 0.122 & 0.000 & -0.923 & -0.238 \\
\hline & & Second & -0.22136 & 0.114 & 0.534 & -0.544 & 0.101 \\
\hline & & Third & -0.24774 & 0.110 & 0.243 & -0.557 & 0.061 \\
\hline & & Fifth & -0.16372 & 0.113 & 1.000 & -0.483 & 0.156 \\
\hline & $\overline{\text { Fifth }}$ & First & $-0,41714^{*}$ & 0.115 & 0.003 & -0.742 & -0.092 \\
\hline & & Second & -0.05763 & 0.108 & 1.000 & -0.361 & 0.246 \\
\hline
\end{tabular}


PREPRINT: Folqué, M., Escrig-Olmedo, E., \& Corzo Santamaría, T. (2021). Sustainable development and financial system: Integrating ESG risks through sustainable investment strategies in a climate change context. Sustainable Development. DOI:

https://doi.org/10.1002/sd.2181

\begin{tabular}{|c|c|c|c|c|c|c|c|}
\hline & & $\begin{array}{l}\text { Third } \\
\text { Fourth }\end{array}$ & $\begin{array}{l}-0.08402 \\
0.16372\end{array}$ & $\begin{array}{l}0.103 \\
0.113\end{array}$ & $\begin{array}{l}1.000 \\
1.000\end{array}$ & $\begin{array}{l}-0.374 \\
-0.156\end{array}$ & $\begin{array}{l}0.206 \\
0.483\end{array}$ \\
\hline \multirow[t]{20}{*}{ Social Risk Score Bonferroni } & \multirow[t]{4}{*}{ First } & Second & $0,55943^{*}$ & 0.152 & 0.003 & 0.132 & 0.987 \\
\hline & & Third & $0,56058^{*}$ & 0.146 & 0.001 & 0.150 & 0.971 \\
\hline & & Fourth & $0,46585^{*}$ & 0.159 & 0.034 & 0.019 & 0.913 \\
\hline & & Fifth & $0,54384^{*}$ & 0.150 & 0.003 & 0.120 & 0.968 \\
\hline & \multirow[t]{4}{*}{ Second } & First & $-0,55943^{*}$ & 0.152 & 0.003 & -0.987 & -0.132 \\
\hline & & Third & 0.00115 & 0.136 & 1.000 & -0.381 & 0.383 \\
\hline & & Fourth & -0.09358 & 0.149 & 1.000 & -0.514 & 0.327 \\
\hline & & Fifth & -0.01559 & 0.141 & 1.000 & -0.412 & 0.380 \\
\hline & \multirow[t]{4}{*}{$\begin{array}{l}\text { Third } \\
\end{array}$} & First & $-0,56058^{*}$ & 0.146 & 0.001 & -0.971 & -0.150 \\
\hline & & Second & -0.00115 & 0.136 & 1.000 & -0.383 & 0.381 \\
\hline & & Fourth & -0.09473 & 0.143 & 1.000 & -0.498 & 0.309 \\
\hline & & Fifth & -0.01674 & 0.134 & 1.000 & -0.394 & 0.361 \\
\hline & \multirow[t]{4}{*}{ Fourth } & First & $-0,46585^{*}$ & 0.159 & 0.034 & -0.913 & -0.019 \\
\hline & & Second & 0.09358 & 0.149 & 1.000 & -0.327 & 0.514 \\
\hline & & Third & 0.09473 & 0.143 & 1.000 & -0.309 & 0.498 \\
\hline & & Fifth & 0.07799 & 0.148 & 1.000 & -0.339 & 0.495 \\
\hline & \multirow[t]{4}{*}{$\overline{\text { Fifth }}$} & First & $-0,54384^{*}$ & 0.150 & 0.003 & -0.968 & -0.120 \\
\hline & & Second & 0.01559 & 0.141 & 1.000 & -0.380 & 0.412 \\
\hline & & Third & 0.01674 & 0.134 & 1.000 & -0.361 & 0.394 \\
\hline & & Fourth & -0.07799 & 0.148 & 1.000 & -0.495 & 0.339 \\
\hline \multirow{20}{*}{$\begin{array}{l}\text { Governance Risk Bonferroni } \\
\text { Score }\end{array}$} & \multirow[t]{4}{*}{ First } & Second & $0,37856^{*}$ & 0.104 & 0.003 & 0.084 & 0.673 \\
\hline & & Third & $0,34194^{*}$ & 0.100 & 0.007 & 0.059 & 0.625 \\
\hline & & Fourth & $0,42165^{*}$ & 0.109 & 0.001 & 0.114 & 0.729 \\
\hline & & Fifth & $0,60206^{*}$ & 0.104 & 0.000 & 0.310 & 0.894 \\
\hline & \multirow[t]{4}{*}{ Second } & First & $-0,37856^{*}$ & 0.104 & 0.003 & -0.673 & -0.084 \\
\hline & & Third & -0.03662 & 0.093 & 1.000 & -0.299 & 0.226 \\
\hline & & Fourth & 0.04309 & 0.103 & 1.000 & -0.246 & 0.332 \\
\hline & & Fifth & 0.22350 & 0.097 & 0.212 & -0.049 & 0.496 \\
\hline & \multirow[t]{4}{*}{ Third } & First & $-0,34194^{*}$ & 0.100 & 0.007 & -0.625 & -0.059 \\
\hline & & Second & 0.03662 & 0.093 & 1.000 & -0.226 & 0.299 \\
\hline & & Fourth & 0.07971 & 0.098 & 1.000 & -0.198 & 0.357 \\
\hline & & Fifth & $0,26012^{*}$ & 0.092 & 0.050 & 0.000 & 0.520 \\
\hline & \multirow[t]{4}{*}{ Fourth } & First & $-0,42165^{*}$ & 0.109 & 0.001 & -0.729 & -0.114 \\
\hline & & Second & -0.04309 & 0.103 & 1.000 & -0.332 & 0.246 \\
\hline & & Third & -0.07971 & 0.098 & 1.000 & -0.357 & 0.198 \\
\hline & & Fifth & 0.18041 & 0.102 & 0.768 & -0.106 & 0.467 \\
\hline & \multirow[t]{4}{*}{$\overline{\text { Fifth }}$} & First & $-0,60206^{*}$ & 0.104 & 0.000 & -0.894 & -0.310 \\
\hline & & Second & -0.22350 & 0.097 & 0.212 & -0.496 & 0.049 \\
\hline & & Third & $-0,26012^{*}$ & 0.092 & 0.050 & -0.520 & 0.000 \\
\hline & & Fourth & -0.18041 & 0.102 & 0.768 & -0.467 & 0.106 \\
\hline
\end{tabular}

*. The mean difference is significant at the 0.05 level.

Table 6. ANOVA to test the differences in means between SI funds generations in terms of carbon risk scores.

\begin{tabular}{llccccc}
\hline & Sum of Squares & df & Mean Square & F & Sig. \\
\hline Carbon Risk Score & Between Groups & 347.876 & 4 & 86.969 & 19.296 & $0.000^{* * *}$ \\
& & & & & & \\
& Within Groups & 2587.141 & 574 & 4.507 & & \\
& Total & 2935.017 & 578 & & & \\
\hline
\end{tabular}

*** The mean difference is significant at the 0.01 level 
PREPRINT: Folqué, M., Escrig-Olmedo, E., \& Corzo Santamaría, T. (2021). Sustainable development and financial system: Integrating ESG risks through sustainable investment strategies in a climate change context. Sustainable Development. DOI:

https://doi.org/10.1002/sd.2181

Table 7. POST HOC Tests. Multiple Comparisons

\begin{tabular}{|c|c|c|c|c|c|c|c|}
\hline \multicolumn{3}{|l|}{ Dependent Variable } & \multirow{2}{*}{$\begin{array}{c}\text { Mean } \\
\text { Difference (I-J) }\end{array}$} & \multirow[t]{2}{*}{ Std. Error } & \multirow[t]{2}{*}{ Sig. } & \multicolumn{2}{|c|}{$95 \%$ Confidence Interval } \\
\hline & & & & & & Lower Bound & $\begin{array}{l}\text { Upper } \\
\text { Bound }\end{array}$ \\
\hline \multirow{20}{*}{$\begin{array}{l}\text { Carbon Risk Bonferroni } \\
\text { Score }\end{array}$} & First & Second & $1,89779^{*}$ & 0.294 & 0.000 & 1.071 & 2.725 \\
\hline & & Third & $1,68881^{*}$ & 0.281 & 0.000 & 0.897 & 2.481 \\
\hline & & Fourth & $2,18152^{*}$ & 0.306 & 0.000 & 1.320 & 3.043 \\
\hline & & Fifth & $2,33061^{*}$ & 0.291 & 0.000 & 1.511 & 3.150 \\
\hline & Second & First & $-1,89779^{*}$ & 0.294 & 0.000 & -2.725 & -1.071 \\
\hline & & Third & -0.20898 & 0.263 & 1.000 & -0.951 & 0.533 \\
\hline & & Fourth & 0.28373 & 0.289 & 1.000 & -0.532 & 1.099 \\
\hline & & Fifth & 0.43282 & 0.274 & 1.000 & -0.338 & 1.204 \\
\hline & Third & First & $-1,68881^{*}$ & 0.281 & 0.000 & -2.481 & -0.897 \\
\hline & & Second & 0.20898 & 0.263 & 1.000 & -0.533 & 0.951 \\
\hline & & Fourth & 0.49271 & 0.277 & 0.756 & -0.287 & 1.273 \\
\hline & & Fifth & 0.64180 & 0.260 & 0.140 & -0.092 & 1.375 \\
\hline & Fourth & First & $-2,18152^{*}$ & 0.306 & 0.000 & -3.043 & -1.320 \\
\hline & & Second & -0.28373 & 0.289 & 1.000 & -1.099 & 0.532 \\
\hline & & Third & -0.49271 & 0.277 & 0.756 & -1.273 & 0.287 \\
\hline & & Fifth & 0.14909 & 0.287 & 1.000 & -0.659 & 0.957 \\
\hline & Fifth & First & $-2,33061^{*}$ & 0.291 & 0.000 & -3.150 & -1.511 \\
\hline & & Second & -0.43282 & 0.274 & 1.000 & -1.204 & 0.338 \\
\hline & & Third & -0.64180 & 0.260 & 0.140 & -1.375 & 0.092 \\
\hline & & Fourth & -0.14909 & 0.287 & 1.000 & -0.957 & 0.659 \\
\hline
\end{tabular}

*. The mean difference is significant at the 0.05 level.

Table 8. Summary of statistically significant differences of means between SI funds generations

\begin{tabular}{|c|c|c|c|c|c|}
\hline & Generation 1 & Generation 2 & Generation 3 & Generation 4 & Generation 5 \\
\hline $\begin{array}{c}\text { Generation } 1 \\
\text { Negative } \\
\text { screening }\end{array}$ & & $\begin{array}{l}\text { Sustainability Risk } \\
\text { Score } \\
\text { Env. Risk Score } \\
\text { Soc. Risk Score } \\
\text { Gov. Risk Score } \\
\text { Carbon Risk Score } \\
\end{array}$ & $\begin{array}{l}\text { Sustainability Risk Score } \\
\text { Env. Risk Score } \\
\text { Soc. Risk Score } \\
\text { Gov. Risk Score } \\
\text { Carbon Risk Score }\end{array}$ & $\begin{array}{l}\text { Sustainability Risk } \\
\text { Score } \\
\text { Env. Risk Score } \\
\text { Soc. Score } \\
\text { Gov. Risk Score } \\
\text { Carbon Risk Score } \\
\end{array}$ & \begin{tabular}{|l} 
Sustainability Risk \\
Score \\
Env. Risk Score \\
Soc. Risk Score \\
Gov. Risk Score \\
Carbon Risk Score \\
\end{tabular} \\
\hline $\begin{array}{c}\text { Generation } 2 \\
\text { Positive } \\
\text { Screening }\end{array}$ & \begin{tabular}{|l} 
Sustainability Risk \\
Score \\
Env. Risk Score \\
Soc. Risk Score \\
Gov. Risk Score \\
Carbon Risk Score \\
\end{tabular} & & & & \\
\hline $\begin{array}{c}\text { Generation } 3 \\
\text { Negative + } \\
\text { Positive } \\
\text { Screening }\end{array}$ & \begin{tabular}{|l|} 
Sustainability Risk \\
Score \\
Env. Risk Score \\
Soc. Risk Score \\
Gov. Risk Score \\
Carbon Risk Score \\
\end{tabular} & & & & \\
\hline $\begin{array}{c}\text { Generation } 4 \\
\text { Neg. or and } \\
\text { Pos. } \\
\text { Screening }+ \\
\text { Engagement }\end{array}$ & \begin{tabular}{|l|} 
Sustainability Risk \\
Score \\
Env. Risk Score \\
Soc. Risk Score \\
Gov. Risk Score \\
Carbon Risk Score \\
\end{tabular} & & & & \\
\hline
\end{tabular}


PREPRINT: Folqué, M., Escrig-Olmedo, E., \& Corzo Santamaría, T. (2021). Sustainable development and financial system: Integrating ESG risks through sustainable investment strategies in a climate change context. Sustainable Development. DOI:

https://doi.org/10.1002/sd.2181

\begin{tabular}{|c|l|l|l|l|}
\hline $\begin{array}{c}\text { Generation } \mathbf{5} \\
\text { Impact }\end{array}$ & $\begin{array}{l}\text { Sustainability Risk } \\
\text { Investment }\end{array}$ & Gov. Risk Score & & \\
& $\begin{array}{l}\text { Score } \\
\text { Env. Risk Score } \\
\text { Soc. Risk Score } \\
\text { Gov. Risk Score } \\
\text { Carbon Risk Score }\end{array}$ & & & \\
\hline
\end{tabular}

